possessed a fine collection of sections of early embryos, all cut and stained by himself. I well remember the wistful sadness which crept into his voice as he once told me of a solitary gap in one very long series of slides. Bryce was staining one of these huge slides when his wife came in and informed him that she had lost her purse. Bryce laid the stide on the bench for a few moments while he spoke to her, and when he picked it up again he discovered to his horror that he had put the slide down with the sections next the wood. Alas! the precious slide was ruined. As Bryce said, "The purse turned up all right, but my sections -well, I couldn't replace them".

Prof. Bryce was an active golfer and a keen fisher. man. He was also a microscopical artist of the highest calibre. The numerous beautiful illustrations from his pencil in Quain's "Embryology" bear witness to the quality of his skill in this difficult form of art.

E.-ASHWORTH UNDERWOOD

\section{Mr. E. G. Boulenger}

The sudden death of Edward George Boulenger at the early age of fifty-seven came as a shock to his many friends and especially to his old colleagues at the London Zoo, and at the Savile Club where he was a well-known and popular member. A week before his death, on April 30, he had been working in the library at the Zoo, taking notes for a book on popular zoology on which he was engaged. He then seemed in the best of spirits and was obviously enjoying his well-earned retirement at Polperro in Cornwall, devoting himself to writing, the contemplation of wild life, and the entertainment of his friends, among whom his hospitality was a byword. His fund of stories and anecdotes was inexhaustible, and his knowledge of food and wine and his ready wit made him a most agreeable host.

Boulenger's knowledge of the exhibition of reptiles, amphibians and fishes and the conditions necessary to their well-being in captivity was unrivalled. In this respect he was the perfect showman. His name will always be associated at the Zoo with the great freshwater and sea-water Aquarium which was opened in 1924. Previous to this he had been curator of reptiles for thirteen years, a post in which he was succeeded by Miss Joan Procter when he took up the directorship of the Aquarium. In 1938, on the retirement of Dr. Burgess Barnett, who had succeeded Miss Procter on her death in 1931, Boulenger took over the Reptile House again and ran it in conjunction with the Aquarium until the outbreak of war. In the "Centenary History" of the Zoo published in 1929, Sir Peter Chalmers Mitchell paid tribute to Boulenger in these words: "The Society owes its unique Aquarium in large measure to the knowledge, perseverance and enthusiasm of one person, Mr. E. G. Boulenger, now its Director".

Like many other buildings in the Gardens, Boulenger's Aquarium suffered during the Second World War as the result of bombing, but the fresh-water section has already been repaired, and it is hoped that the sea-water and tropical sections will be opened by the end of the year in their original form. The Aquarium stands as a lasting monument to Boulenger's vigorous efforts and creative ability; his name is certainly one of those outstanding in the history of the Zoo.

Boulenger was a good linguist, speaking both French and German. This stood him in excellent stead on the many journeys he made to the Continent and elsewhere in search of interesting specimens for the Aquarium and Reptile House. He was educated at St. Paul's School, but owed a great deal of his knowledge of reptiles to his father, the late G. A. Boulenger, who was for many years the greatest living authority on cold-blooded vertebrates. $\mathrm{He}$ served in both the First and Second World Warsin the first as an observer in the Balloon Section of the Royal Flying Corps, and in the second as a major on the General Staff at the War Office. He had a facile pen and in addition to many semi-scientific papers and articles on reptiles and fishes, he found time to publish several books dealing with animals, among which "A Naturalist at the Dinner Table", "A Naturalist at the Zoo", and "Apes and Monkeys" will be best remembered.

Edward Boulenger's death, following as it does so closely on that of his old chief, Sir Peter Chalmers Mitchell, with whom he worked so long, brings to a colleague a flood of memories of days and sometimes nights of hard work, made easy by the sense of achievement and ultimate triumph over many difficulties.

GEOFFREY M. Vevers

\section{Mr. C. A. Watts}

THE death occurred on May 15 of Mr. Charles Albert Watts, founder of C. A. Watts and Co., Ltd., and the Rationalist Press Association, Ltd. Born in 1858, he was the son of Charles Watts, an intimate colleague of Charles Bradlaugh, G. J. Holyoake and other reformers. At the age of twelve he was apprenticed to Austin Holyoake, who printed Bradlaugh's publications; and shortly after the death of Holyoake, Watts, though still in his teens, took sole charge of the printing business and began to initiate publishing ventures, chiefly in the field of advanced thought in religion and philosophy.

In the eighties and nineties the dissemination of books of this type was attended by many difficulties, not the least of which was the reluctance of the distributing trades to handle and display works which challenged the traditional religious outlook. Mr. Watts set himself to overcome these difficulties by founding the Rationalist Press Association, Ltd., with a double purpose: to provide funds which would enable original works and reprints to be issued at moderate prices; secondly, to create close relations with potential buyers. It scored its first success by issuing sixpenny reprints of the chief works of Spencer, Darwin, T. H. Huxley, Tyndall and others at a time when this type of production was confined to fiction of established popularity. These reprints later developed into the now well-known Thinker's Library, consisting of small handy volumes on fundamental problems of philosophy, religion and science, which has achieved a distinctive position in modern thought.

WE regret to announce the following deaths :

Sir Charles Marston, known for his interest in archæological exploration in Egypt and the Middle East, on May 21, aged seventy-nine.

Prof. J. W. W. Stephens, F.R.S., emeritus professor of tropical medicine in the University of Liverpool, on May 17, aged eighty. 